\title{
Enhancing Safety at Airline Operations Control Centre
}

\author{
Ing. Lukáš Ǩasa \\ Department of Air Transport \\ CTU in Prague, Faculty of Transportation Sciences \\ Prague, Czech Republic
}

\author{
Ing. Vladimír Plos \\ Laboratory of Aviation Safety and Security \\ Department of Air Transport, CTU in Prague, Faculty of \\ Transportation Sciences \\ Prague, Czech Republic \\ e-mail: plosvlad@fd.cvut.cz
}

\begin{abstract}
In recent years a new term of Safety Management System (SMS) has been introduced into aviation legislation. This system is being adopted by airline operators. One of the groundbased actors of everyday operations is Operations Control Centre (OCC). The goal of this article has been to identify and assess risks and dangers which occur at $\mathrm{OCC}$ and create a template for OCC implementation into SMS.
\end{abstract}

Keywords- safety; management; system; operations; control; centre; center; commercial; airline; risk; assessment; process; analysis

\section{INTRODUCTION}

In recent years a stress has been put on documentation of risk assessments and corrective actions taken by aviation subjects. This process is nowadays known as Safety Management System (SMS). There is, however, a controversy between two goals of maximum safety and minimum costs. It is every company's decision to choose their optimum. This optimum has to be achieved by application of approved SMS methodology.

SMS is being implemented among other subjects as well, such as ATS providers and airports. I would like to focus this study on commercial airline operators. Their operations is very complex, the main application of SMS is in their flight operations and maintenance. There is one ground-based actor active during airline's flight operations and it is called OCC. In the following text, I will define the role of OCC and assess its influence to the overall safety of an airline's operations.

\section{THE TERM OCC}

\section{A. OCC definition}

The existence of OCC is usually dictated by a need for operations control. Services provided by OCC can be, and for small companies usually are, out-sourced. The decision whether to outsource or set up an organizational unit within the company is based on type of operations, ability to use some or all of benefits provided by OCC and last but not least financial expenses.

A term "OCC" is perceived as a workstation, a single position within airline's structure. An airline is here defined as a commercial air transport operator or operator of jet aircraft in general. Special commercial airplane operations, e.g. agricultural flying, were not considered. While OCC most possibly exists with these as well it differs significantly with its structure and assigned tasks. MCC (maintenance control centre) is not included in OCC as well as crew planning and scheduling. Both are easily separable from OCC as there is a distinct border of duties and responsibilities. OCC does not need to have those positions included in itself and usually does not include them.

The main task of OCC is to secure operations and do it in the safest and most economical manner practical. A number of processes and procedures help do just that, with the core processes described in this article. Information flow maintaining is another task of OCC. This consists of systematically information gathering and distribution, which help secure safe and economical operations. Last but not least, OCC processes flight documentation, which translates mostly into flight planning.

As a general practice, more than one dispatchers work at OCC. A dispatcher is an employee assigned to OCC, officially this position is described in ICAO Annexes as a flight dispatcher/flight operations officer. The number of dispatchers on duty is proportional to the amount of flights on the specified day. There is an increased demand for complex knowledge for single dispatcher operations. This usually happens in smaller companies, where the traffic is not high. On the other hand, large companies use specialized workstations dedicated for specific actions and must tackle a problem of dispatcher interaction/resource management. For the purpose of this article, these interaction topics have not been studied.

\section{B. Legislation basis}

The establishment of OCC as a workstation is not discussed in legislation. However, its existence is derived from the general need for operations supervision and control. The need is amongst other described in following legislation:

- ICAO Doc 9376 PREPARATION OF AN OPERATIONS MANUAL, 
- ICAO Doc 8335 Manual of Procedures for Operations Inspection, Certification and Continued Surveillance,

- Commission Regulation (EU) No 965/2012.

Dispatcher training is described in ICAO Doc 7192 Part D3. Specific requirements for flight dispatcher are laid down in ICAO Annex 1. Furthermore, UCL (Czech republic CAA) has created an examination outline for dispatcher testing and publishes it as "Examination outline no. 13".

The SMS is regulated by the new ICAO Annex 19. European requirements are once again represented in Commission Regulation (EU) No 965/2012.

The IOSA audit has become a world-wide standard these days. This audit has been created by IATA and one of eight chapters is solely dedicated to "Operation Control and Flight Dispatch". Basic requirements for an OCC as a workplace are laid down along with those for dispatcher training. SMS is another important topic in IOSA standards. Almost all of recommendations concerning SMS are going to become a standard by 2016, a timeline generally set by many regulators.

\section{Process analysis}

At the beginning of the analysis processes, which take place at and go through OCC, had to be defined. These processes differ from operator to operator due to varying internal structure and goals assigned to OCC in general. The most common processes were identified and are described in the text below.

Operational monitoring. It is a passive process, when OCC receives information about different aspects of the operation such as passenger and payload information. This information flows through the whole company and usually comes from external sources. The information is very important for handling and airport companies to assure smooth operation. $\mathrm{OCC}$ is only monitoring and gathering such information.

Technical status monitoring. Firstly, OCC should always have knowledge of the actual technical status of aircraft they are operating. This status consists of inherent characteristics given by the aircraft's design parameters and of temporary deviations from that state. Technical status is used by OCC for flight planning and aircraft scheduling. It is vital that dispatcher has the most up to date and correct information about the technical status of the aircraft.

Flight monitoring. Monitoring of the progress of a flight is conducted in different ways. The most common is monitoring departure and expected and actual arrival times. Dispatcher then provides an alerting service based on provisions given in ICAO Annex 11. Besides this, the flight monitoring serves a much more down-to-earth purpose. It is very important to maintain awareness about position of all aircraft of the company for operational reasons.

Operational control. This process may contain a wide range of activities. The ultimate goal is to secure a smooth operation by eliminating and preventing irregularities and safety hazards. A very large portion of this process is performed as a decisionmaking action and virtually, only objectively defined part is the information distribution process.
Flight planning. OCC tries to conduct flight planning to achieve safe and economical operation. It is a very complex process in which the dispatcher uses different sources of information and areas of knowledge to create a final product of operational flight plan and ATS flight plan.

Emergency response. This process ensures an adequate response of the operator to emergency and abnormal situations and ensures a return to normal operations afterwards. Incidents, serious incidents and accidents are considered emergency situations as per ICAO Annex 13 definitions. Every event that has a significant impact on operations may be considered abnormal. To a limited extent, the definition of an abnormal situation is a responsibility of the operator.

Dispatcher training. Generally, this is a very controversial topic. There is a great pressure laid on dispatchers to exercise a correct decision making techniques. The dispatcher needs a sufficient amount of information as well as knowledge for an efficient decision making. The knowledge base is very wide range of areas. On the other hand, the depth of knowledge does not have to be great in many areas. Unfortunately, the legislation is very weak on this topic, mainly in European area.

OCC management. A process of OCC management contains usual manager duties and responsibilities.

Information gathering and operating procedures creation. The last of OCC manager's processes where they set up operating procedures and indirectly controls the operations. The most important information source is an OCC duty report. Evaluating these are vital for OCC manager.

\section{HAZARD IDENTIFICATION}

As a first step the hazard identification has been carried out. A number of latent hazards and risks were drawn from this analysis.

\section{A. Hazard identification methodology}

I chose and ARMS methodology, which was put together by a group of professionals in an area of aviation safety management. This group consisted of more than 30 people. The group itself has been set up in 2007. The group merged with ECAST SMS working group to avoid doubling efforts. Most of the activity seized in 2010 when last version of ARMS methodology has been published. All of the outputs have been presented to ICAO that declared ARMS ICAO SMS standards conform.

This methodology is mainly targeted at aircraft operators but it is applicable to other aviation subjects as well, such as maintenance organizations and ATS providers.

\section{B. Hazard identification sources}

There are 3 sources for hazard identification. The first is my own work experience which is more than 3 years as a flight operations officer at the time of this article completion. I am also a holder of ICAO dispatcher licence.

The second source is consultation with topic experts from various companies. All those experts have been in an OCC field for a long time and have completed several brainstorming sessions with me. 
The last source was a questionnaire which was distributed among dispatchers in Czech Republic. Responds were not treated upon the basis of their quantity and all answers were treated as equally important.

\section{Latent hazards}

Latent hazards are conditions that create a possibility of an accident. The SHELL model was a basis for this identification and identified hazards are listed below:

- completion and completeness of flight documentation,

- adverse weather conditions,

- incomplete or inaccurate information,

- time pressure,

- an unknown problem,

- external pressure to OCC (mostly economically driven),

- low motivation, poor communication and general mood of dispatchers,

- risk underestimation,

- $\quad$ pilot-dispatcher trust,

- medical fitness,

- multitasking and distractions,

- high, low or oscillating workload,

- absence of breaks,

- verbally communicated information,

- duty handover,

- malfunctioned or faulty technical or SW equipment,

- $\quad$ ergonomics

- incorrect operation procedures

\section{Risk analysis}

Two impacts of risks were evaluated during analysis. The first impact is an "operational" safety, this is the usual way the term safety is perceived. The second impact is a "financial" safety. The consequence of absence of this kind of safety is obviously a financial loss. There is a short description together with evaluated operational and financial safety impacts for each risk/safety issue. The scale includes "Accept" and "Monitor" do not require immediate actions while "Secure", "Improve" and "Stop" usually require corrective actions. The risks represented by these values are not corrected for OCC defences, which usually lower all of the risks to acceptable levels.

1) ERP not activated (financial-Improve, operational-not applicable)
An event that requires ERP activation is falsely evaluated and ERP is not activated. The company does is not alerted and emergency units not established.

2) Emergency situation information (financial-Stop, operational-not applicable)

This time, the ERP is activated as it should have been. However, not all relevant information is collected and passed to emergency units. This might lead to misleading information by those units while handling very sensitive data such as passenger names, their medical state, the nature of the event etc.

3) Secured operation during an emergency period (financial-Monitor, operational-Accept)

The operation has to go on during a period of emergency response. There is a high degree of danger that OCC will concentrate its focus on the emergency situation and a potential for error goes up for the remaining traffic.

4) Aircraft location information (financial-not applicable, operational-Stop)

This information is one of the basic information that the company needs to perform an operational supervision and control.

5) Operational messages (financial-Improve, operational-not applicable)

Operational messages contain information relevant to aircraft handling, e.g. time of departure and arrival, number of passengers, amount and distribution of payload etc. The absence of such timely information possesses a risk of delays and handling discrepancies.

6) Serious political situation (financial-Secure, operational-Improve)

Airline business is a global business. It is and has been a target of acts of violence as it is very fragile and susceptible to such acts. Political situation together with armed conflict affects aviation very much. Also strikes are quite common to have effect on air transport.

7) Flight schedule and maintenance conflict (financialSecure, operational-not applicable)

This is a part of monitoring duties of OCC. One of the active activities the dispatcher does is to ensure that maintenance does not overlap flight schedule.

8) Aircraft technical restriction (financial-Stop, operational-Monitor)

Not always flies the aircraft in a perfect technical state. It is usual practice that it is dispatched with minor malfunction according to MEL. Some of those malfunctions may have an impact on aircraft operation. These are the most important for a dispatcher.

9) Flight planning (financial-Stop, operational-Stop) 
Flight planning consists of many activities and gathers a lot of information from various sources put together to produce one final product, the flight plan.

10) Flight planning data (financial-Stop, operationalImprove)

In order to perform a quality flight planning, dispatcher needs quality information. That usually is information about planned payload and passengers. Stop)

11) Aircraft performance (financial-Improve, operational-

The performance calculation is a very important part in aircraft dispatching. Those calculations assure that the aircraft will safely perform the take-off and landing manoeuvres. Same calculations are made by the flight crew when performing the flight.

12) ATC interaction (financial-Stop, operational-Stop)

ATC services are practically always used during commercial flights. The dispatcher must know how to file a flight plan and interact with ATC system in general.

13) Payload information (financial-not applicable, operational-Accept)

Information about payload must be passed on to the crew. One of dispatcher's duties is to do just that, especially for dangerous goods and other special loads.

14) Bad operational decision (financial-Improve, operational-Monitor)

One of core OCC activities is operations control. This is mostly decision-making process and relies on qualities of individual dispatchers. Factors such as common sense and previous experience play an important part. Therefore, it is very easy to make a mistake by forgetting, misunderstanding etc.

15) Operational changes, flight schedule creation (financial-Stop, operational-Stop)

An operational decision precedes every change and it mostly concerns amendment of the flight schedule. OCC has the authority and responsibility to make such changes in a dedicated time window.

16) Crew qualification and standards (financial-Improve, operational-Secure)

Crew planning and scheduling is not direct OCC responsibility. However, failure of such process may result in an irregularity which is then OCC responsibility. It is therefore very advisable to prevent such risks rather than react to their realisation.

\section{CONCLUSION}

The model of OCC has been established. It has been found that dispatcher face significant requirements for knowledge and abilities which is contrary to the legislation. The responsibility for quality dispatcher training is then put on companies. A logical presumption that $\mathrm{OCC}$ is a central point for information flow has been confirmed, not all of the information is directly useful for OCC though.

As a general conclusion from risk analysis, we may establish that OCC has a significant impact on economy of the operation and plays a vital role in securing this. On the other hand, the only process that has a real potential to harm operational safety is flight planning.

\section{REFERENCES}

[1] L19 Letecký předpis, Řízení bezpečnosti. Praha: Ministerstvo dopravy ČR: Úrad procivilní letectví, listopad 2013.

[2] ICAO Doc 9859 Safety Management Manual. ISBN: 978-92-9249-2144. 3.vydání. Montréal, Quebec, Kanada: International Civil Aviation Organization, 2013

[3] CLARKE, M. D. D. Irregular airline operations: a review of the state-ofthepractice in airline operations control. Journal of Air Transport Management. Cambridge, MA, USA: Elsevier Science Ltd. 1998, č. 4, s. 67-76. ISSN 0969-6997

[4] The ARMS Methodology for Operational Risk Assessment in Aviation Organisations [online]. ARMS WORKING GROUP. [cit. 2014-01-01]. Available at: http://www.skybrary.aero/bookshelf/books/1141.pdf

[5] L1 Letecký předpis o způsobilosti leteckého personálu civilního letectví. Praha: Ministerstvo dopravy ČR: Úřad pro civilní letectví, listopad 2013.

[6] Nařízení Rady (EHS) č. 3922/91 o harmonizaci technických požadavků a správních postupů v oblasti civilního letectví. Brusel, Belgie: Rada EHS, září 2010

[7] IATA - IATA Operational Safety Audit (IOSA) [online]. Internationa Air Transport Association (IATA). [cit. 2014-04-20]. Available at: http://www.iata.org/whatwedo/safety/audit/iosa/Pages/index.aspx

[8] Nařízení Komise (EU) č.965/2012, kterým se stanoví technické požadavky a správní postupy týkající se letového provozu podle nařízení Evropského parlamentu a Rady (EHS) č. 216/2008. Brusel, Belgie Evropská komise, ř́ijen 2012.

[9] Acceptable Means of Compliance (AMC) and Guidance Material (GM) to Part-ORO. Consolidated version - Issue 2. Köln, Něměcko: European Aviation Safety Agency, duben 2014.

[10] BAZARGAN, M. Airline operations and scheduling. Aldershot: Ashgate, 2004. ISBN 978-0-7546-3616-8.

[11] ICAO Doc 8335 Manual of Procedures for Operations Inspection, Certification and Continued Surveillance. ISBN: 978-92-9231-476-7. 5. vydání. Montréal, Quebec, Kanada: International Civil Aviation Organization, 2010.

[12] Fatigue Risk Management Guide Systems - Implemenation Guide for Operators - 1st Edition [online]. IATA; ICAO; IFALPA. [cit. 2014-0423]. Available at: http://www.iata.org/publications/Documents/FRMS\%20Implementation $\% 20$ Guide $\% 20$ for $\% 20$ Operators $\% 201$ st $\% 20$ Edition-\%20English.pdf 